\title{
Networked Education Systems and the Flow of PISA-Induced References
}

\author{
Erika L. Kessler \\ Teachers College, Columbia University \\ Oren Pizmony-Levy \\ Teachers College, Columbia University
}

** Work in Progress **

December 28, 2020

Word Count (including references and tables): 8,284

\begin{abstract}
International large-scale assessments (ILSAs) contribute to the internationalization of the education policymaking process. As they initiate and design education reforms, stakeholders worldwide make implicit and explicit references to the experience/achievement of foreign countries. This chapter analyzes the social structure that emerges from the flow of these references. We draw on an original dataset of texts published in newspapers in 23 countries following the release of the 2012 Programme for International Student Assessment (PISA). Using network analysis techniques, we demonstrate the centralized and hierarchical nature of the PISA-Induced Reference Societies Network (PIRS Network). Comparisons with other global networks suggest that the flow of references is closely related to cultural relations (comembership in international governmental organizations) and to some extent to economic relations (trade import/export). We discuss these patterns and call for more research that focuses on relations between countries and their implications for education policy and practice.
\end{abstract}

\section{Keywords:}

Globalization; International large-scale assessments (ILSAs); Programme for International Student Assessment (PISA); Public Discourse; Social Network Analysis (SNA) 


\section{Introduction}

Scholars often point to the recent proliferation of international large-scale assessments (ILSAs) as an example for the impact of globalization on education (Kamens \& McNeely, 2010). International organizations - such as the International Association for the Evaluation of Educational Achievement (IEA) and the Organization for Economic Co-operation and Development (OECD) - conduct ILSAs in a range of subjects including mathematics, science, and reading. In a choreographed fashion (Maddox, 2018), international organizations disseminate the results of these assessments through dense reports, ranking tables and infographics, and press releases. By doing so, ILSAs integrate different countries into one statistical or commensurate space (Lingard, 2011; Seller \& Lingard, 2013) and this process facilitates the internationalization of education policymaking (e.g., transnational borrowing and lending of policy and practice). ${ }^{1}$

Further, ILSAs produce transnational anxiety about the "learning crisis" and its implications to economic development (Baker \& LeTendre, 2005; Auld, Rappleye \& Morris, 2018). Economists such as Eric Hanushek and Ludger Wößmann (2007; 2010), for example, argue that cognitive skills - as measured by ILSAs - contribute to economic growth. That is why, they argue, governments should improve their education system. Indeed, ILSAs have generated a flurry of debate around educational reform (Meyer \& Benavot, 2013; Sahlberg, 2014). One interesting aspect of this debate is the implicit and explicit reference to the experience and achievement of foreign countries (Addey, Sellar, Steiner-Khamsi, Lingard \& Verger, 2017; Steiner-Khamsi \& Waldow, 2018; Waldow, 2017). A case in point is the educational pilgrimage to Finland in the early 2000s, following its top performance in the OECD's Programme for International Student Assessment (PISA). ${ }^{2}$

In this chapter, we offer a fresh look at reference societies in public discourse about ILSAs. For the purpose of this study, we define public discourse as any form of communication (e.g., texts and visuals) that is accessible to members of the public and that could influence public opinion. Specifically, we use network analysis techniques to examine the social structure of references to foreign countries in news articles and opinion pieces published in 23 countries in the week following the release of PISA 2012 (December 2-10, 2013). We call this structure PISAInduced Reference Societies Network (PIRS Network). We address the following research questions:

RQ \#1: What characterizes the PIRS Network?

RQ \#2: To what extent does the PIRS Network reflect other international networks?

The analysis of the PIRS Network - as reflected in public discourse - is important for at least two reasons. First, it helps to discover how the whole comes to be greater than sum of its parts. Scholars have examined reference societies in PISA-related public discourse in individual

\footnotetext{
${ }^{1}$ Note on language: International Organizations refer to participants in ILSAs as "economies" (OECD) or "education systems" (IEA). For the sake of simplicity, we refer to participants as countries. We acknowledge that not all countries in the sample are independent nation-states.

2 The OECD coordinates and administers PISA to 15-year-old students triennially since 2000. PISA covers three subject domains: mathematics, science, and reading. Every cycle, the assessment alternates major subject domains. In its fifth cycle, PISA 2012, the major subject was mathematics.
} 
countries and in small-n comparisons. In the current study, we complement this line of research by adding a new perspective on the system that emerge from multiple interactions between countries. Second, analysis of the PIRS Network helps to investigate how different types of relations between countries (e.g., cultural and economic) shape policy debates about education. In other words, the current study provides an opportunity to explore the role of larger global processes in education policymaking.

\section{ILSAs and Public Discourse}

One of the overarching goals of ILSAs is to inform and enrich public discourse about the quality of education in different countries (Howie \& Plomp, 2005). Shortly after the release of a new ILSA report, the news media begins with frenzied attention. For some time, newspapers worldwide publish articles highlighting the standings of nations in international ranking, and commenting on the implications of these results. Following the release of PISA 2012, for example, the New York Times published an article titled "American 15-year-olds lag, mainly in math, on international standardized test" (Rich, 2013), and the Israel-based Ha'aretz published an article titled "Israeli student achievement does not leave much room for optimism" (Kashti, 2013). These articles challenge educational systems and schools to implement changes and mobilize stakeholders to improve the quality of education.

This chapter contributes to the growing literature on ILSAs and public discourse. Rather than analyzing the content of texts published in newspapers, we focus on mentions of achievement and/or experience of foreign countries in the context of PISA 2012. We conceptualize these mentions as indicators for the PIRS Network.

Following the immense expansion of ILSAs, scholars have begun to explore public discourse about these assessments. Their motivations are twofold. First, most stakeholders learn about ILSAs from newspapers, legacy media channels (radio and television) and social media (e.g., Pizmony-Levy \& Torney-Purta, 2018). Although international organizations responsible for ILSAs make the reports available to the public free of charge, these reports are not necessarily accessible to the public due to their scientific/technical language and jargon. ${ }^{3}$ Given this, and the fact that people are more likely to seek news and information from the news media, it is important to understand how the media "filter and translate scientific information to the public" (Epstein, 1996:22). Second, scholars treated public discourse as a "window" to the policymaking process within a given country (e.g., Pizmony-Levy, 2018; Pons 2016, 2017; Stack, 2007; Steiner-Khamsi, 2003). Media outlets are historical record of public discourse and actions by individuals and organizations. Scholars investigated how journalists and stakeholders interpreted and framed ILSAs results to advance education change and policy reform.

We organize the growing body of research on ILSAs and public discourse by mapping studies on two dimensions: the number of cases in the analysis (single vs. multiple) and the period of the

\footnotetext{
${ }^{3}$ ILSAs are an advanced scientific and technical endeavor (National Research Council, 2002). They involve complicated sampling techniques of schools and students, development of reliable questionnaires and instruments, translation and adaptation to various languages. Further, ILSAs are based on state-of-the-art statistical methods aimed to produce comparable and valid scores (e.g., Item-Response Theory [IRT]). International organizations report results from each cycle of ILSAs in thick and dense volumes that include numerous charts, graphs, and tables as well as technical notes.
} 
analysis (cross-sectional vs. longitudinal). Figure 1 maps 23 published studies on these two dimensions. Prior research tends to look at single countries using a longitudinal perspective (10 out $23=43 \%$ ). Nancy Green Sarsisky (2015), for example, examined the representation of PISA in four American newspapers between 2000 and 2012. Another common research design includes multiple countries using a cross-sectional perspective $(7$ out $23=30 \%$ ). Florian Waldow, Keita Takayama, and Youl-Kwan Sung (2014), for example, compared how news media in Australia, Germany and South Korea depicted the success of the 'Asian Tiger' countries in PISA 2009. Other configurations or research design on ILSAs and public discourse are less common, as illustrated in Figure 1. Our study complements past research by using network analysis techniques to shed light on interactions between countries, reflected in public discourse.

\section{Figure 1 - about here}

Two central themes dominate research on ILSAs and public discourse; both themes inform the current study. The first theme speaks to the overall tone of texts and the ways in which journalists and speakers mentioned in texts interpret the results of ILSAs. Early on, Gita SteinerKhamsi (2003) identified three types of reactions to ILSA league tables: scandalization, glorification, and indifference. Steiner-Khamsi argued these responses are useful for generating policy reform (i.e., through framing "problems" and "solutions"). Building on her work, other scholars have examined factors that could explain variation in public responses to ILSA results (for recent examples, see articles in the edited volume by Steiner-Khamsi \& Waldow, 2018). Further, studies on reactions to ILSA results have found news media uncritically endorse the validity and reliability of ILSA results (Stack, 2007), and policymakers and elites leverage results based on their local objectives (Dixon et al., 2013; Takayama, 2008, 2009, Pons, 2012).

The second theme speaks to the concept "reference societies". Jürgen Schriewer and his colleagues (Schriewer, 1990; Schriewer \& Martinez, 2004) suggested that local education discourse(s) often include mentions of foreign education systems that explicitly serve as exemplars of emulation (or avoidance). These "reference societies" assist stakeholders to establish reform coalitions and to address debate over reform by drawing on the experience of external education system. ILSAs and the practice of ordinalization of countries in ranking tables (Sorensen \& Robertson, 2020) provide many opportunities for "reference societies". Therefore, scholars have interrogated the emergence of "reference societies" and the role of local context in this process. Building on this conceptualization, scholars have demonstrated how stereotyped prior perceptions determine the ways in which the media framed success in ILSAs (Waldow, 2014). Further, scholars have pointed to the use of "reference societies" as a means to scandalize education systems and make ILSAs more meaningful at the local level (Pizmony-Levy, 2018).

In an editorial of a recent special issue, Gita Steiner-Khamsi and Florian Waldow (2018) summarize the plethora of studies on ILSAs in public discourse and argue: "[...] rarely do these studies adopt a critical comparative perspective that allows them to see how PISA translation relates to ongoing debates and power relations among the various policy networks in a country" (p. 564). Inspired by this call to pay more attention to networks, in this chapter we advance past research by exploring news media in a relatively large number of countries and documenting the interactions between these countries. We assess interactions through analysis of all "reference 
societies" included in news articles and opinion pieces surrounding PISA 2012. In addition to visualizing the PIRS Network, we also compare this structure to other types of relationships that exist between countries. Next, we offer a short review of theories of globalization to articulate different types of relationships between countries (e.g., economic and cultural).

\section{Globalization, Networks, and Education Policymaking}

In this section, we situate the study of the PIRS Network within globalization studies. Scholars offer different definitions for the term globalization; a common feature of these definitions is the focus on connectivity between countries and people (Stromquist, 2002). Originating in the work of Appadurai (1996, 2002) and Castells (2000), scholars now conceptualize the global flows and networks of people, ideas, money, media, practices, and technology as contributing to the expansion of transnational relations and global influence. The expansion of global networks have given rise to an emphasis on universalizing, scientific evidence that can efficiently diagnose and reform education (Baker \& Wiseman, 2005; Spring, 2010). However, the dynamic interaction of global and local dimensions is what facilitates globalization in education (Stromquist \& Monkman, 2014). Therefore, it is crucial for studies to take into account the relational context of how countries engage with PISA results. In what follows we present three arguments in globalization studies, each of them emphasizes one type of relationship between countries: economics, culture, and distance/time.

First, economic globalization shapes education policy and practice. This argument highlights the rapid integration of countries into the world economy, with increasing trade, pressure from international corporations, and competition between countries (Stromquist \& Monkman, 2014). In this context, the role of education is to promote human capital for economic growth (Hanushek \& Wößmann, 2015; Stromquist \& Monkman, 2014). Indeed, the OECD frames PISA outputs as means to elevate a country's economic growth through education. For the OECD and many policymakers, high performance on PISA (and other ILSAs) is an indicator for a future competitive workforce. Given this argument, we expect that countries with strong economic relationships will mention each other within public discourse about PISA. We therefore test the following proposition:

\section{Hypothesis 1: The PIRS Network has a positive correlation with the network of international trade.}

Second, and related, globalization compresses time and space. Studies linking global networks of economic markets and policy reform often rely on measures of distance between two given countries to help explain the expansion of international trade agreements, exports/imports of goods and services, as well as other geo-political trends (e.g., Abakumova \& Primierova, 2020; Stavytskyy et al., 2019; Yatsenk et al., 2017). A paradox in this line of research finds that as globalization of trade and the speed of communication networks increase, the anticipated 'death of distance' does not exist and in fact distance between two countries and the predicted extent of economic trade remains important (Leamer \& Storper, 2001; Hirst \& Thompson, 2002; Abakumova \& Primierova, 2020). In other words, the shorter the distance between two countries corresponds with the extent of trade and economic exchange between them. Given the emphasis on economic growth presented in Hypothesis 1, we expect that countries will mention 
neighboring countries within public discourse about PISA. Therefore, we offer the following proposition:

Hypothesis 2: The PIRS Network has a negative correlation with the network of international trade.

Third, cultural globalization is a substantial driver of education change. This argument focuses on rising information flows and cultural exchange, with both processes leading to a considerable degree of resemblance across countries (Rizvi, 2000; Spring, 2008; Stromquist \& Monkman, 2014). World Culture Theory, for example, posits that education systems are becoming similar due to a top-down process whereby new ideas and models regarding the responsibilities of the nation-state are developed in transnational spaces and later adopted by individual nation-states (Meyer et al. 1997). These transnational spaces include international governmental and nongovernmental organizations (IGOs and INGOs) such as the United Nations and Education International (a global union federation of teachers' trade unions); these organizations bring together stakeholders to engage in international agreements, conferences, and communities. Country embeddedness in transnational spaces facilitates cultural process - e.g., normative and mimetic pressures - that contribute to organizational isomorphism. In addition to international organizations, scholars also point to the importance of international communication (e.g., World Wide Web, movies, and television) and population mobility (e.g., employment-based immigration and international students). Robin Shileds (2012) demonstrates how different aspects of cultural globalization - international student mobility and co-membership in IGOs are interrelated. Given this argument, we expect that countries with strong cultural relationships will mention each other within public discourse about PISA. We therefore test the following propositions:

Hypothesis 3a: The PIRS Network has a positive correlation with the co-membership network of countries in international organizations.

Hypothesis 3b: The PIRS Network has a positive correlation with the network of international student mobility.

Before we delve into the data and methods behind our study, we offer a brief introduction to networks and social networks analysis (SNA). A network consists of "a finite set or sets of actors and the relation or relations defined on them" (Wasserman \& Faust, 1994, p. 20). In other words, a network is a set of socially relevant nodes that are possibly connected by one or more relations (Marin \& Wellman, 2011); a network includes some actors that are connected and other actors that might be disconcerted or isolated from each other. Actors (or nodes) are discrete individuals or groups. Examples of actors are students in a classroom, schools within an educational system, articles/documents in a given domain, or nation-states in the world system. Relationships (or edges) are the ties that connect actors. Relationships among actors can be of different kinds, and each type facilitates a corresponding network. In the current study, we study the PIRS Network that consists of countries (actors) and interactions between as reflected in mentions in newspapers (relationships).

SNA is one of the theoretical and methodological developments that are rarely used in the field of Comparative and International Education (CIE; for review see: Pizmony-Levy, 2021). One 
area where CIE scholars have frequently engaged SNA is the study of international student mobility (e.g., Barnett, Lee, Jiang \& Park, 2016; Macrander, 2017; Shields, 2012). This chapter contribute to the broad CIE literature by engaging SNA in the study of ILSAs and public discourse.

\section{Data \& Methods}

We draw on an original dataset of 266 news articles and opinion pieces published between December 2 and 10, 2013 in 112 newspapers in 23 countries. All the texts reported the cognitive test results of PISA 2012. Table 2 presents the countries represented in this study. More than two-thirds of these countries (16 out of 23) are OECD members; the rest are OECD partners. Half of these countries (12 out of 23) scored above the OECD average, about two-fifths of the countries (9 out of 23) scored below the OECD average, and the rest - two countries scored at the OECD average.

\section{Table 2 - about here}

The second author trained and supervised 22 research assistants participating in a graduate-level seminar dedicated to the social analysis of ILSAs (see Pizmony-Levy, 2020). Research assistants chose an education system where they had sufficient fluency and familiarity to read and analyze news articles. They received a detailed protocol to identify at least ten texts (i.e., news articles and opinion pieces) published in at least two newspapers (protocol available upon request). Research assistants received a three-hour training. This included an overview of the codebook and rationales for the elements. To ensure reliability of coding, research assistants practiced using the codebook with news articles published in the United States.

To analyze the ways in which newspapers report on PISA, we used a standardized codebook (available upon request) informed by previous work (Pizmony-Levy, 2013, 2018). Each article was coded at two levels. The first is the article level; information and codes that pertain to the article as a whole (e.g., title, location, length, tone, and visuals). For example, we used SteinerKhamsi's typology (2003) categorizing political reaction to performance on ILSAs to capture the overall tone of the article. The second is the speaker level; information and codes that relate to individuals whose "speech acts" were reported in the articles (e.g., governmental officials; researchers, and OECD representatives). Different speakers offer diverse framings and interpretations of reality -- the results of PISA 2012.

A key indicator in the codebook was mentions of foreign countries (whether mentioned by the author of the text and/or by those quoted in the text). Research assistants coded all texts that included a mention of any foreign education system (yes $=1$, no $=0$ ). Then, they extracted the full names of the countries mentioned in the text. Once data entry was completed, we prepared the dataset for analysis by keeping mentions to specific countries and removing all other generic mentions (e.g., "Asian countries" and "OECD countries"). We then transformed the information into columns, where each column represents a specific country (columns are coded 1 if country name is mentioned and 0 if otherwise).

Social Networks 
The primary network in our analysis is the PIRS Network. Recall that in the original dataset, the unit of analysis is a news article/opinion piece. Because we are interested in relationships between countries, we aggregated the data at the country level. This transformation resulted in 23 x 59 matrix, with 23 rows representing the countries in our sample and 59 columns representing the countries mentioned in the news articles/opinion pieces in our sample. In this matrix, each cell included a count for the number of mentions of each education system by newspapers in a given education system. Because Pearson correlations require equally sized square matrices, we reshaped the initial matrix by adding rows for all countries that mentioned in the news articles/opinion pieces but were not included in our sample. For these rows, the cells included no information (missing data). The final matrix is directed, valued, and balanced (59 x 59; see Figure 1 for illustration). For example, data for Australia contain three mentions of Canada; and data for Canada contain one mention of Belgium, one mention of Brazil, and eight mentions of Canada.

\section{Figure 1 - about here}

Based on the theoretical framework presented above, we compared the PIRS Network to four other global networks: International Governmental Organizations, international student mobility, world trade, and geographic distance. We use the first two networks to assess claims about cultural globalization; and we use the latter two networks to evaluate competing claims about economic globalization and geographic regionalization.

International Governmental Organizations (IGOs). We draw on data from the Correlates of War $(\mathrm{COW})$ project, which facilitates the collection and dissemination of accurate and reliable quantitative data in international relations (Pevehouse, Nordstrom, McManus, and Jamison, 2020). From the COW dataset, we constructed an affiliation network (Wasserman and Faust, 1994) of nation states co-memberships in IGOs in 2011. A tie between a pair of nation states represent the number of IGOs they have in common. France and the Netherlands had the strongest link (117); Chinese Taipei (Taiwan) and several European countries (Czech Republic, Hungary, Liechtenstein and Serbia) had the weakest link (2). To ensure the robustness of the analysis, we use two versions of the IGOs network: Sums of cross products (also known as overlaps) and Bonacich (1972) normalization to sums of cross products.

International student mobility. We draw on data published by UNESCO Institute for Statistics. Countries report the country of origin for all incoming students pursuing tertiary education (ISCED levels 5 and 6). Scholars have used this data to operationalize directed links between countries: the number of students moving from country A to country B in a given year (for more information and analysis, see Shields, 2012).

World trade. We draw on the United Nations' Commodity Trade Statistics database, which is "a repository of official international trade statistics and relevant analytical tables" (UN Comtrade, 2020). Countries report detailed imports and exports statistics; the UN Statistics Division then standardized the data for public use. Scholars have used this data to operationalize directed links between countries: The extent of trade between country A and country B. 
Geographic distance. We draw on the GeoDist database published by the French Institute for Research into International Economics (Centre d'Études Prospectives et d'Informations Internationales; CEPII). From the GeoDist database, we constructed an undirected network of the distance (in kilometers) between most country pairs across the world. The distance network measures the extent to which geography shape the PIRS network.

\section{Limitations}

Our study provides new insights for scholars of international and comparative education, but it is not without limitations. We call readers' attention to three main limitations. First, the analysis of media coverage of PISA 2012 results is limited to one week, immediately after the release of the results. It is possible that the quality of the media coverage is different when journalists and stakeholders have more time to engage with the results. Second, the sample of countries is a convenience sample (non-random) and it is not representative of all education countries participating in PISA 2012. ${ }^{4}$ Third, the coding instrument captures any reference to foreign countries and does not distinguish between positive or negative references. While limited, our dataset allows us to examine how news media in different social contexts inform the public on the results of PISA.

\section{Findings}

We begin by describing the sample of news articles and opinion pieces in the dataset $(n=266)$. Three-quarters of these texts (74\%) referred to PISA results of foreign countries. The prevalence of references, however, varies across countries. In three cases - Hong Kong, the Netherlands, and the United Kingdom - all texts included references. In four cases - Israel, South Korea, New Zealand, and Uruguay - no more than half of the texts included references. The following excerpts illustrate how newspapers reference the PISA results of foreign countries:

- Australia: "Australia's ranking in international education league tables only tells you so much, because in truth there are many Australias. Teenagers in the top socio-economic quartile of this country are achieving in math at a level that would put them in the top five countries in the world and on par with standout performer Korea. By contrast, the Australia as represented by students in the lowest socio-economic quartile would be placed significantly below the OECD average, in about 40th position and on par with Greece" (Tovey, 2013).

- Ireland: "The global results show Asian countries outperform the rest of the world, with Shanghai-China and Singapore top in math, which was the main focus of the 2012 tests" (Murray, 2013).

- Mexico: "Students from Shanghai, Singapore, Hong Kong, Taipei and South Korea obtain the best educational performance [...] at the opposite extreme is Peru [...] the best results at the regional level are obtained by Chile, followed by Mexico, Uruguay, and Costa Rica" (Dinero en Imagen, 2013).

- United States: "In the Asian countries that took the top spots - including Singapore, South Korea and areas of China - families spend heavily on private tutoring to prepare their children for college entrance examinations that closely resemble the PISA tests [...]

\footnotetext{
${ }^{4}$ PISA 2012 included 65 countries (i.e., the population). While the representation of OECD members and partners in the population was almost even, their representation in the sample was more than two-thirds (52\% vs. $70 \%$ ). The sample includes more countries that preformed above the OECD average ( $52 \%$ vs. $35 \%$ ) and less countries that preformed below the OECD average (35\% vs. $54 \%$ ).
} 
The reasons that some countries do well (or poorly) are complicated. Finland, for instance, has historically been successful on the PISA tests - so much so that governments, including California's, have sent delegations there to figure out the educational magic" (Los Angeles Times Editorial Board, 2013).

Table 3 compares between texts that include and texts that do not include references to PISA results of foreign countries. While we find no statistically significant difference between the groups in terms of the article overall tone, we do find difference in terms of content, discourse, and background information about PISA. Texts with references are more likely than other texts to present PISA results using ranking $(82.8 \%$ vs. $60.3 \%)$. Similarly, texts with references are more likely to focus on international competition (differences between countries: $39.8 \% \mathrm{vs}$. $25.5 \%$ ) and less likely to focus on domestic inequalities (differences within countries: 15.2\% vs. $65.5 \%$ ). Another common characteristic of texts with references is the inclusion of background information about PISA (e.g., the full name behind the acronym, the role of the OECD, and the limitations of the assessment).

Table 3 - about here

\section{Network Structure and Indicators}

Figure 2 is a visual representation of the PIRS Network. Each square, or node, represents one country in the dataset. Black nodes are countries in our sample (23), and grey nodes are countries mentioned in the newspapers but not included in the sample (36). A line between two nodes represent a connection between countries. Recall, this is a directed network; the direction of the arrow in the end of the line indicates the direction of the connection (country $\mathrm{A}>$ mentioned the results of $>$ country B). The size of the each node reflects the number of countries that referenced that country (in-degree).

\section{Figure $2-$ about here}

What sort of a structure is the PIRS Network? The emerging network is sparse and has a high degree of centralization. The density of the network is low: Only $29.7 \%$ of all possible ties in the network are active. Countries do not reference all other countries that participated in PISA 2012. Rather, countries are selective in their referencing. The ties are relatively concentrated, with a small number of countries receiving much of the references (in-degree centralization measure $=$ .231). On average, countries receive reference from seven foreign countries (average of indegree). Ten countries receive reference from more than 10 countries: China (20), South Korea (20), Finland (19), Singapore (19), Hong Kong (18), Japan (16), Canada (13), Taiwan (13), Poland (12), and Estonia (12). These countries perform well on the PISA 2012 ranking table or show meaningful improvements throughout the waves of PISA (PISA, 2013). Together the top ten most referenced countries receive $44.0 \%$ of all the active ties in the network.

The structure shows additional interesting pattern: Low level of reciprocity. The arc reciprocity, or the interchange between two countries, is low: Only $23.7 \%$ of all ties between countries are reciprocal. With directed networks, as the one presented in Figure 2, there are three possible ties: Null tie (A and B are not connected), reciprocated tie (A and B send to each other), and asymmetric (A sends to B or B sends to A). Scholars suggest network that has a predominance of 
balanced connections (i.e., null or reciprocated) may be a more "equal" or "stable" network and less hierarchical than network with a predominance of asymmetric connections (Wasserman and Faust, 1994). Figure 2 includes several countries that are relatively active in terms of sending links (referencing foreign countries; out-degree) but these countries are not receiving much links (reference attention from other countries; in-degree). This is the case with Great Britain (outdegree: 39; in-degree: 2) and Uruguay (out-degree: 20; in-degree: 1). In other words, the structure of the PIRS Network is unequal and hierarchical.

\section{Correlations and Regression}

In the final part of the analysis, we examine the extent to which the reference flows relate to other global networks and variables identified above, including IGOs membership, international student mobility, world trade, and geographic distance. We begin with simple correlations, using the QAP (Quadratic Assignment Procedure) correlation procedure in UCINET 6.708. Correlations were calculated between country pairs in 2011. Table 4 presents correlations coefficients for two versions of the PIRS Network: valued (number of references) and dichotomized (yes/no). All correlations are statistically significant, but they are relatively weak.

$\underline{\text { Table } 4 \text { - about here }}$

The world trade coefficients $(\mathrm{r}=.226, \mathrm{p}<.001 ; \mathrm{r}=.192, \mathrm{p}<.001)$ suggest there is a relationship between reference flows and the extent to which countries are involved in trade exchange (import/export). One possible interoperation of this pattern echoes claims about economic globalization. The PIRS Network reflects the competitive pressures that guide international trade: Countries refer to others with whom they have existing economic relationships.

The IGOs membership coefficients suggest there is a relationship between reference flows and the extent to which countries are co-members in IGOs. The pattern holds whether we operationalize flows as valued or dichotomized; we find no difference between the two versions of the IGOs membership network (i.e., simple and normalize). This lends support to claims about cultural globalization. Increased embeddedness in international organizations is associated with normative and mimetic processes that lead to isomorphism. Countries refer to others with whom they share similarities.

The international student mobility coefficients $(\mathrm{r}=.117, \mathrm{p}<.05 ; \mathrm{r}=.123, \mathrm{p}<.01)$ offer further support to claims about cultural globalization. There is a relationship between reference flows and the student flows. Countries refer to countries to whom they send students.

The coefficients for distance $(\mathrm{r}=-.152, \mathrm{p}<.01 ; \mathrm{r}=-.170, \mathrm{p}<.01)$ suggest there is a reverse relationship between reference flows and geographic distance between countries. Countries refer to neighboring countries or to countries in their region. This pattern lends support for claims about regional policy learning and regional competition.

In order to assess the independent effect of global networks and variables on reference flows, we estimated four multivariate regression models (Table 5). We estimated two models for each version of the PIRS Network: valued (number of references) and dichotomized (yes/no). For each of these version, we included two versions of the IGOs membership network (i.e., simple 
and normalize). The pattern is simple and straightforward. When we adjust for other networks and variables, across all four models, the coefficient for IGOs membership remains statistically significant. The pattern lends further support to claims about cultural globalization: Countries refer to others with whom they share similarities.

\section{$\underline{\text { Table } 5 \text { - about here }}$}

\section{Conclusion}

Following the release of ILSAs reports, local actors and stakeholders face many decisions when engaging and interpreting these reports. They can choose to ignore the results (Green Saraisky, 2015). Local actors can also choose to ignore the outcomes of other countries and to focus on their respective education system. Finally, local actors can choose to engage the results of other countries and to use their achievement and experience with education reforms. If so, they can choose which countries to mention and which countries to ignore. Through analysis of public discourse in 23 countries and network techniques, we examined the reactions of local actors and stakeholders to the release of PISA 2012.

We find that majority of texts in newspapers (74\%) mentioned PISA results of foreign countries. These texts also include language of ranking, competition between countries, and background information about the OECD and PISA. The circulation of news media on PISA results emphasizes the commensuration work of ILSAs and the drive toward ordinalization (Espeland \& Stevens, 1998; Fourcade, 2016; Sorenson \& Robertson, 2020).

What characterizes the PIRS Network? Overall, the network is coherent, sparse and quite centralized. Ten countries, most of them are part of the "Asian Tigers", occupy the center of the network. Many countries in the sample referenced these countries, possibly because their students preform very well on PISA or because they have demonstrated significant improvement and therefore might be role models for other countries. In addition, the network is not reciprocal and there is evidence for regionalism where countries tend to reference other countries in their geographic region.

To what extent does the PIRS Network reflect other international networks? We find evidence to support multiple theories of globalization (see Table 4). Those who emphasize the role of economic globalization could point to the correlation between the PIRS network the world trade network. Those who emphasize the role of cultural globalization could point to the correlation between the PIRS network and two other networks: IGOs membership and international student mobility. Preliminary evidence from regression models, however, suggest that cultural globalization offer a more robust correlation with the PIRS network. The external references made by news media in our study demonstrate an interlinking of ordinalization across educational systems. Not only are countries relying on the outcomes of PISA to compare the position of education systems, but also by comparing and referencing specific countries, there emerges a social structure of ordinalization that is weighted with cultural meaning.

Future research on "reference societies" networks that emerge from public discourse on ILSAs (e.g., the PIRS Network) could develop in different directions. First, scholars could extend the current analysis to additional countries that participated in PISA 2012, especially from OECD partners and countries preforming below the OECD average. Second, scholars could extend the 
analysis to earlier and later waves of PISA to assess changes in the size and structure of the PIRS Network. Third, with larger samples and networks, scholars could examine correlations with additional global networks, including development aid and military conflict. Fourth, scholars could extend the analysis to other ILSAs, namely TIMSS and ICCS, to evaluate whether there are differences based on the type of assessment (domains, curriculum-based vs. competencybased) and the international organization sponsoring the assessment (OECD vs. IEA). Fifth, scholars could turn to qualitative interviews to understand the social process that produces public discourse on ILSAs. By asking journalists and speakers about the how they choose which countries to mention in their texts, scholars could shed light on motivations and practices (e.g., valuation and selection).

Taken together these patterns suggest that local actors - media and stakeholders - translate and respond to ILSAs (e.g., PISA) according to their relational context. While scholars often emphasize the importance of the global and local contexts, our study point to a third context the extent to which countries are connected to each other. To better understand education policy in a globalized world, scholars should pay more attention to networks within and between countries. 


\section{References}

Abakumova, J., \& Primierova, O. (2020). Globalization and export flows between Eurasian Economic Union countries: A gravity model approach. SHS Web of Conferences, 74, 06001.

Addey, C., Sellar, S., Steiner-Khamsi, G., Lingard, B., \& Verger, A. (2017). The rise of international large-scale assessments and rationales for participation. Compare: $A$ Journal of Comparative and International Education, 47(3), 434-452.

Appadurai, A. (1996). Modernity Al Large: Cultural Dimensions of Globalization. U of Minnesota Press.

Appadurai, A. (2002). Disjuncture and Difference in the Global Cultural Economy. In Susanne Schech and Jane Haggis (eds.), Development: A Cultural Studies Reader (pp. 157-167). Oxford, England: Blackwell.

Auld, E., Rappleye, J., \& Morris, P. (2019). PISA for Development: How the OECD and World Bank shaped education governance post-2015. Comparative Education, 55(2), 197-219.

Baker, D., \& LeTendre, G. K. (2005). National differences, global similarities: World culture and the future of schooling. Stanford University Press.

Bonacich, P. (1972). Technique for analyzing overlapping memberships. Sociological Methodology, 4, 176-185.

Borgatti, S.P., Everett, M.G. and Freeman, L.C. (2002). UCINET for Windows: Software for Social Network Analysis. Harvard, MA: Analytic Technologies.

Dixon, R., C. Arndt, M. Mullers, J. Vakkuri, K. Engblom-Pelkkala, and C. Hood. 2013. “A Lever for Improvement or a Magnet for Blame? Press and Political Responses to International Educational Rankings in Four EU Countries." Public Administration 91 (2): 484-505.

Epstein, S. (1996). Impure Science: AIDS, Activism, and the Politics of Knowledge. Berkley: University of California Press.

Green Saraisky, N. (2015). The politics of international large-scale assessment: The Programme for International Student Assessment (PISA) and American education discourse, 20002012 (Doctoral dissertation, Columbia University).

Hanushek, E. A., \& Woessmann, L. (2015). The Knowledge Capital of Nations: Education and the Economics of Growth. MIT Press.

Hanushek, E. A., \& Wößmann, L. (2007). The role of school improvement in economic development (No. w12832). National Bureau of Economic Research.

Hanushek, E. A., \& Wößmann, L. (2010). Education and economic growth. Economics of education, 60-67.

Hirst, P., \& Thompson, G. (2002). The Future of Globalization. Cooperation and Conflict, 37(3), 247-265.

Howie, S., and T. Plomp. (2005). International Comparative Studies of Education and Large-scale Change. In Bascia, N., Cumming, A., Datnow, A., Leithwood, K., \& Livingstone, D. (Eds.). International Handbook of Educational Policy (Vol. 13). Springer Science \& Business Media, Dordrecht.

$\mathrm{Hu}, \mathrm{Z}$. (2020). Local meanings of international student assessments: An analysis of media discourses of PISA in China, 2010-2016. Compare: A Journal of Comparative and International Education, $0(0), 1-21$.

Kamens, D. H., \& McNeely, C. L. (2010). Globalization and the growth of international educational testing and national assessment. Comparative education review, 54(1), 5-25. 
Kashti, O. (December 3, 2013). Israeli Student Achievement Does Not Leave much Room for Optimism. Ha'aretz.

Leamer, E., \& Storper, M. (2001). 'The economic geography of the Internet age" WP 8450.

Lingard, 2011

Los Angeles Times Editorial Board (December 9, 2013). Are America's students falling behind the world? Los Angeles Times.

Maddox, B. (Ed.). (2018). International large-scale assessments in education: Insider research perspectives. Bloomsbury Publishing.

Meyer, H. D., \& Benavot, A. (Eds.). (2013, May). PISA, power, and policy: The emergence of global educational governance. Symposium Books Ltd.

Murray, N. (December 4, 2013). No complacency despite good results. Irish Examiner.

Pevehouse, J. C., Nordstrom, T., McManus, R. W., \& Jamison, A. S. (2020). Tracking organizations in the world: The Correlates of War IGO Version 3.0 datasets. Journal of Peace Research, 57(3), 492-503.

Pizmony-Levy, O. (2018). Compare globally, interpret locally: international assessments and news media in Israel. Globalisation, Societies and Education, 16(5), 577-595.

Pizmony-Levy, O. (2020). Teaching Corner: Exploring the World of International Large-Scale Assessments. CIES Newsletter-Perspectives, summer/fall issue: 12-13.

Pizmony-Levy, O., \& Torney-Purta, J. (2018). How journalists and researchers communicate results of international large-scale assessments. CADMO.

Pons, X. (2011). What do We Really Learn from PISA? The Sociology of Its Reception in Three European Countries (2001-2008). European Journal of Education 46 (4): 540-548.

Pons, X. (2016). Tracing the French policy PISA debate: A policy configuration approach. European Educational Research Journal, 15(5), 580-597.

Pons, X. (2017). Fifteen years of research on PISA effects on education governance: A critical review. European Journal of Education, 52(2), 131-144.

Razo, A. (2016). Bringing Networks into Comparative Politics (J. N. Victor, A. H. Montgomery, \& M. Lubell, Eds.; Vol. 1). Oxford University Press.

Rizvi, F. (2000). International education and the production of global imagination. In N. C. Burbules \& C. A. Torres (eds.), Globalization and Education: Critical Perspectives. Psychology Press.

Sahlberg, P. (2014). Finnish lessons 2.0: What can the world learn from educational change in Finland? Teachers College Press.

Schatz, M. (2015). Toward One of the Leading Education-Based Economies? Investigating Aims, Strategies, and Practices of Finland's Education Export Landscape. Journal of Studies in International Education, 19(4), 327-340.

Schmidt, G. (2003). Reactions of Participating Countries as Reflected in Their Press: A Comparison. European Education, 35(4), 58-69.

Schriewer, J. \& Martinez, C. (2004) Constructions of internationality in education, in: G. Steiner- Khamsi (Ed.) The global politics of educational borrowing and lending. New York, Teachers College Press, 29-53.

Schriewer, J. (1990). The method of comparison and the need for externalization: Methodological criteria and sociological concepts, in: J. Schriewer, in cooperation with B. Holmes (Eds.). Theories and methods in comparative education. Bern, Peter Lang, 352. 
Sellar, S., \& Lingard, B. (2013). Looking East: Shanghai, PISA 2009 and the reconstitution of reference societies in the global education policy field. Comparative Education, 49(4), 464-485. Shields, R. (2013). Globalization and International Student Mobility: A Network Analysis. Comparative Education Review, 57(4), 609-636.

Sjøberg, S. (2016). OECD, PISA, and globalization: The influence of the international assessment regime. Education Policy Perils: Tackling the Tough Issues, 102-133.

Spring, J. (2008). Research on Globalization and Education. Review of Educational Research, $78(2), 330-363$.

Spring, J. (2014). Globalization of Education: An Introduction. Routledge.

Stack, M. (2006). Testing, Testing, Read All about It: Canadian Press Coverage of the PISA Results. Canadian Journal of Education / Revue Canadienne de l'éducation, 29(1), 4969.

Stack, M. (2007). Representing School Success and Failure: Media Coverage of International Tests. Policy Futures in Education 5(1): 100-110.

Stavytskyy, A., Kharlamova, G., Giedraitis, V., \& Sengul, E. C. (2019). Gravity model analysis of globalization process in transition economies. Journal of International Studies, 12(2).

Steiner-Khamsi, G. (2003). The Politics of League Tables. Journal of Social Science Education 2 (1), 1-6.

Steiner-Khamsi, G., \& Waldow, F. (2018). PISA for scandalization, PISA for projection: the use of international large-scale assessments in education policy making - an introduction. Globalisation, Societies and Education, 16(5), 557-565.

Stromquist, N. P., \& Monkman, K. (Eds.). (2014). Globalization and education: Integration and contestation across cultures. R\&L Education.

Takayama, K. (2007). "A Nation at Risk Crosses the Pacific: Transnational Borrowing of the US Crisis Discourse in the Debate on Education Reform in Japan." Comparative Education Review 51 (4): 423-446.

Takayama, K. (2008). “The Politics of International League Tables: PISA in Japan's Achievement Crisis Debate." Comparative Education 44 (4): 387-407.

Tovey, J. (December 4, 2013). Too many losers in divided education system. The Sydney Morning Herald.

Volante, L. (2015). The Impact of PISA on Education Governance: Some Insights from Highly Reactive Policy Contexts. International Studies in Educational Administration (Commonwealth Council for Educational Administration \& Management (CCEAM)), 43(2).

Waldow, F. (2017). Projecting images of the 'good' and the 'bad school': top scorers in educational large-scale assessments as reference societies. Compare: A Journal of Comparative and International Education, 47(5), 647-664.

Waldow, F., Takayama, K., \& Sung, Y. K. (2014). Rethinking the pattern of external policy referencing: Media discourses over the 'Asian Tigers' PISA success in Australia, Germany and South Korea. Comparative Education, 50(3), 302-321.

Wasserman, S., \& Faust, K. (1994). Social network analysis: Methods and applications. Cambridge University Press.

Wiseman, A. W., \& Baker, D. P. (2005). The Worldwide Explosion of Internationalized Education Policy. In D. P. Baker \& A. W. Wiseman (Eds.), Global Trends in Educational Policy (Vol. 6, pp. 1-21). Emerald Group Publishing Limited. 
Yatsenko, O., Meyers, W. H., Iatsenko, O., \& Biletska, I. (2017). Modeling of development processes of bilateral trade and economic integration between countries. 
Table 1: Summary of Literature on ILSAs in News Media Discourse

\begin{tabular}{|c|c|c|}
\hline & Single Case & Multiple Countries \\
\hline $\begin{array}{l}\text { Cross- } \\
\text { Sectional }\end{array}$ & $\begin{array}{c}\text { Dobbins \& Martens (2012) } \\
\text { Takayama }(2008,2010,2018)\end{array}$ & $\begin{array}{c}\text { Dixon et al (2013) } \\
\text { Fladmoe (2011) } \\
\text { Martens \& Niemann (2010) } \\
\text { Pizmony-Levy \& Torney-Purta (2018) } \\
\text { Schmidt (2003) } \\
\text { Sellar \& Lingard (2013) } \\
\text { Waldow et al (2014) }\end{array}$ \\
\hline Longitudinal & $\begin{array}{c}\text { Baroutsis \& Lingard (2017) } \\
\text { Green Saraisky (2015) } \\
\text { Hu (2020) } \\
\text { Liu (2018) } \\
\text { Pizmony-Levy (2018) } \\
\text { Pons (2016) } \\
\text { Stack (2007, 2008) } \\
\text { Waldow (2017) } \\
\text { Yemini \& Gordon (2017) }\end{array}$ & $\begin{array}{c}\text { Davis et al (2020) } \\
\text { Davis \& Wilson (2019) } \\
\text { Takayama et al (2013) }\end{array}$ \\
\hline
\end{tabular}


Table 2: Background information about countries in the study of PISA coverage

\begin{tabular}{|c|c|c|c|c|c|c|}
\hline Country & $\begin{array}{l}\text { OECD } \\
\text { member }\end{array}$ & $\begin{array}{c}\text { Mathematics } \\
\text { mean score }\end{array}$ & $\begin{array}{l}\text { Mathematics } \\
\text { ranking }\end{array}$ & $\begin{array}{l}\text { Mathematics } \\
\text { performance } \\
\text { compared } \\
\text { to OECD mean }\end{array}$ & $\begin{array}{l}\text { Examples of newspapers } \\
\text { in sample }\end{array}$ & $\begin{array}{c}\text { Total } \\
\text { number of } \\
\text { articles in } \\
\text { sample } \\
\end{array}$ \\
\hline Australia & Yes & 504 & 19 & Above & $\begin{array}{l}\text { The Daily Telegraph; The } \\
\text { Sydney Morning Herald }\end{array}$ & 10 \\
\hline Brazil & & 391 & 58 & Below & Extra; O Globo & 10 \\
\hline Canada & Yes & 518 & 13 & Above & $\begin{array}{l}\text { The Globe and Mail; Toronto } \\
\text { Star }\end{array}$ & 22 \\
\hline Chile & Yes & 423 & 51 & Below & El Mercurio; La Tercera & 10 \\
\hline Chinese Taipei & & 560 & 4 & Above & Apple Daily; China Times & 10 \\
\hline France & Yes & 495 & 25 & Not different & $\begin{array}{l}20 \text { minutes; Le Figaro; Le } \\
\text { Monde; L'Obs }\end{array}$ & 20 \\
\hline Germany & Yes & 514 & 16 & Above & $\begin{array}{l}\text { Die Welt; Süddeutsche } \\
\text { Zeitung }\end{array}$ & 10 \\
\hline Hong Kong & & 561 & 3 & Above & $\begin{array}{l}\text { Hong Kong Economic } \\
\text { Journal; Wenhui Po }\end{array}$ & 10 \\
\hline Ireland & Yes & 501 & 20 & Above & Irish Examiner; Irish Times & 10 \\
\hline Israel & Yes & 466 & 41 & Below & $\begin{array}{l}\text { Ha'aretz; Israel Hayom; } \\
\text { Yedioth Ahronoth }\end{array}$ & 10 \\
\hline Japan & Yes & 536 & 7 & Above & Nikkei; Yomiuri & 10 \\
\hline Mexico & Yes & 413 & 53 & Below & El Universal; Milenio & 10 \\
\hline Netherlands & Yes & 523 & 10 & Above & De Telegraaf; de Volkskrant & 10 \\
\hline New Zealand & Yes & 500 & 23 & Above & $\begin{array}{l}\text { Dominion Post; New } \\
\text { Zealand Herald }\end{array}$ & 11 \\
\hline Republic of Korea & Yes & 554 & 5 & Above & Chosunilbo; Seoul Shinmun & 10 \\
\hline Russia & & 482 & 34 & Below & $\begin{array}{l}\text { Lenta (2); Rossiiskaya } \\
\text { Gazeta }\end{array}$ & 10 \\
\hline Shanghai, China & & 613 & 1 & Above & $\begin{array}{l}\text { China Education Daily; } \\
\text { China Education News }\end{array}$ & 10 \\
\hline Singapore & & 573 & 2 & Above & The Straits Times; Today & 20 \\
\hline Spain & Yes & 484 & 33 & Below & El Correo; El Pais & 14 \\
\hline Tukey & Yes & 448 & 44 & Below & Hurriyet; Milliyet; Sozcu & 10 \\
\hline United Kingdom & Yes & 494 & 26 & Not different & Daily Mail; The Guardian & 10 \\
\hline United States & Yes & 481 & 36 & Below & $\begin{array}{l}\text { Boston Global; The } \\
\text { Washington Post }\end{array}$ & 10 \\
\hline Uruguay & & 409 & 55 & Below & El Pais; La Red 21 & 9 \\
\hline
\end{tabular}


Table 3: Characteristics of news stories and opinion pieces, by group

\begin{tabular}{|c|c|c|c|}
\hline & $\begin{array}{l}\text { Texts } \\
\text { with } \\
\text { referenc } \\
\text { es }\end{array}$ & $\begin{array}{c}\text { Texts } \\
\text { without } \\
\text { referenc } \\
\text { es }\end{array}$ & Total \\
\hline $\mathrm{N}(\%)$ & $\begin{array}{c}197 \\
(74 \%)\end{array}$ & $\begin{array}{c}69 \\
(26 \%)\end{array}$ & $\begin{array}{c}266 \\
(100 \%)\end{array}$ \\
\hline \multicolumn{4}{|l|}{ Article tone } \\
\hline Scandalization & 45.4 & 37.7 & 43.4 \\
\hline Glorification & 12.1 & 19.7 & 14.0 \\
\hline Neutral & 32.8 & 26.2 & 31.1 \\
\hline Not sure & 9.8 & 16.4 & 11.5 \\
\hline \multicolumn{4}{|l|}{ Presentation of PISA results } \\
\hline Ranking *** & 82.8 & 60.3 & 76.8 \\
\hline Raw scores + & 39.7 & 27.0 & 36.3 \\
\hline Percentiles/percentages + & 33.3 & 20.6 & 30.0 \\
\hline Other * & 10.3 & 20.6 & 13.1 \\
\hline \multicolumn{4}{|l|}{ Content of text } \\
\hline Discusses implications & 54.1 & 42.6 & 51.1 \\
\hline Includes causal arguments & 53.8 & 52.5 & 53.4 \\
\hline Focuses on differences between countries $* * *$ & 39.8 & 25.5 & 36.3 \\
\hline Focuses on differences within countries $* * *$ & 15.2 & 65.5 & 27.4 \\
\hline Focuses on both types of differences $* * *$ & 45.0 & 9.1 & 36.3 \\
\hline Calls for educational reform & 42.8 & 33.9 & 40.5 \\
\hline \multicolumn{4}{|l|}{ Text provide background information } \\
\hline What PISA acronym stands for? $* * *$ & 64.4 & 39.7 & 57.8 \\
\hline What is PISA? * & 18.4 & 7.9 & 15.6 \\
\hline Who is behind PISA (OECD)? $* *$ & 69.0 & 50.8 & 64.1 \\
\hline Why PISA exists? + & 18.4 & 9.5 & 16.0 \\
\hline What is the methodology behind PISA? & 32.8 & 28.6 & 31.6 \\
\hline Limitations of PISA ** & 10.9 & - & 8.0 \\
\hline
\end{tabular}

Note: ${ }^{* * *} \mathrm{p}<.001,{ }^{* *} \mathrm{p}<.01,{ }^{*} \mathrm{p}<.05,+\mathrm{p}<.10$ 
Table 4: Correlation coefficients for selected global networks

\begin{tabular}{lcc}
\hline & $\begin{array}{c}\text { Valued } \\
\text { network }\end{array}$ & $\begin{array}{c}\text { Dichotomized } \\
\text { network }\end{array}$ \\
\hline Undirected networks: & $.218 * * *$ & $.229 * * *$ \\
IGOs memberships - simple & $.210 * * *$ & $.205 * * *$ \\
IGOs memberships - normalize & $-.152 * *$ & $-.170 * *$ \\
Distance & & \\
Directed networks: & $.117 *$ & $.123 * *$ \\
$\quad$ International student mobility & $.226 * * *$ & $.192 * * *$ \\
$\quad$ World trade & & \\
&
\end{tabular}

Note: $* * * \mathrm{p}<.001,{ }^{* *} \mathrm{p}<.01,{ }^{*} \mathrm{p}<.05,+\mathrm{p}<.10$ 
Table 5: Standardized QAP regression coefficients for selected global networks

\begin{tabular}{lcccc}
\hline & \multicolumn{2}{c}{$\begin{array}{c}\text { Valued } \\
\text { network }\end{array}$} & \multicolumn{2}{c}{$\begin{array}{c}\text { Dichotomized } \\
\text { network }\end{array}$} \\
\hline IGOs memberships - simple & $\begin{array}{c}\text { Model 1 } \\
.294 * * *\end{array}$ & Model 2 & $\begin{array}{c}\text { Model 1 } \\
.270 * * *\end{array}$ & Model 2 \\
IGOs memberships - normalize & & $.223 * * *$ & & $.158 * *$ \\
International student mobility & .054 & .058 & $.083+$ & $.084 *$ \\
World trade & .028 & .079 & -.008 & .046 \\
Distance & .021 & .024 & -.000 & -.026 \\
$\mathrm{R}^{2}$ & .096 & .067 & .085 & .050 \\
& & & & \\
\hline
\end{tabular}

Note: ${ }^{* * *} \mathrm{p}<.001,{ }^{* *} \mathrm{p}<.01,{ }^{*} \mathrm{p}<.05,+\mathrm{p}<.10$ 
Figure 1: Excerpt of directed, valued, and balanced matrix for the PISA-Induced Reference Societies Network

$\begin{array}{lcccccccccccc} & \text { ALB } & \text { ARE } & \text { ARG } & \text { AUS } & \text { AUT } & \text { BEL } & \text { BGR } & \text { BRA } & \text { CAN } & \text { CHE } & \text { CHL } & {[\ldots]} \\ \text { ALB } & & & & & & & & & & & & \ldots \\ \text { ARE } & & & & & & & & & & & & \\ \text { ARG } & & & & & & & & & & & & \ldots \\ \text { AUS } & 0 & 0 & 0 & 0 & 0 & 0 & 0 & 0 & 3 & 0 & 0 & \ldots \\ \text { AUT } & & & & & & & & & & & & \ldots \\ \text { BEL } & & & & & & & & & & & & \ldots \\ \text { BGR } & & & & & & & & & & & & \ldots \\ \text { BRA } & 0 & 0 & 0 & 0 & 0 & 0 & 0 & 4 & 0 & 0 & 1 & \ldots \\ \text { CAN } & 0 & 0 & 0 & 0 & 0 & 1 & 0 & 1 & 8 & 2 & 0 & \ldots \\ \text { CHE } & & & & & & & & & & & & \ldots \\ \text { CHL } & 0 & 0 & 1 & 0 & 0 & 0 & 0 & 2 & 0 & 0 & 3 & \ldots \\ {[\ldots]} & \ldots & \ldots & \ldots & \ldots & \ldots & \ldots & \ldots & \ldots & \ldots & \ldots & \ldots & \ldots\end{array}$


Figure 2: Sociogram for PISA-Induced Reference Societies Network (2013)

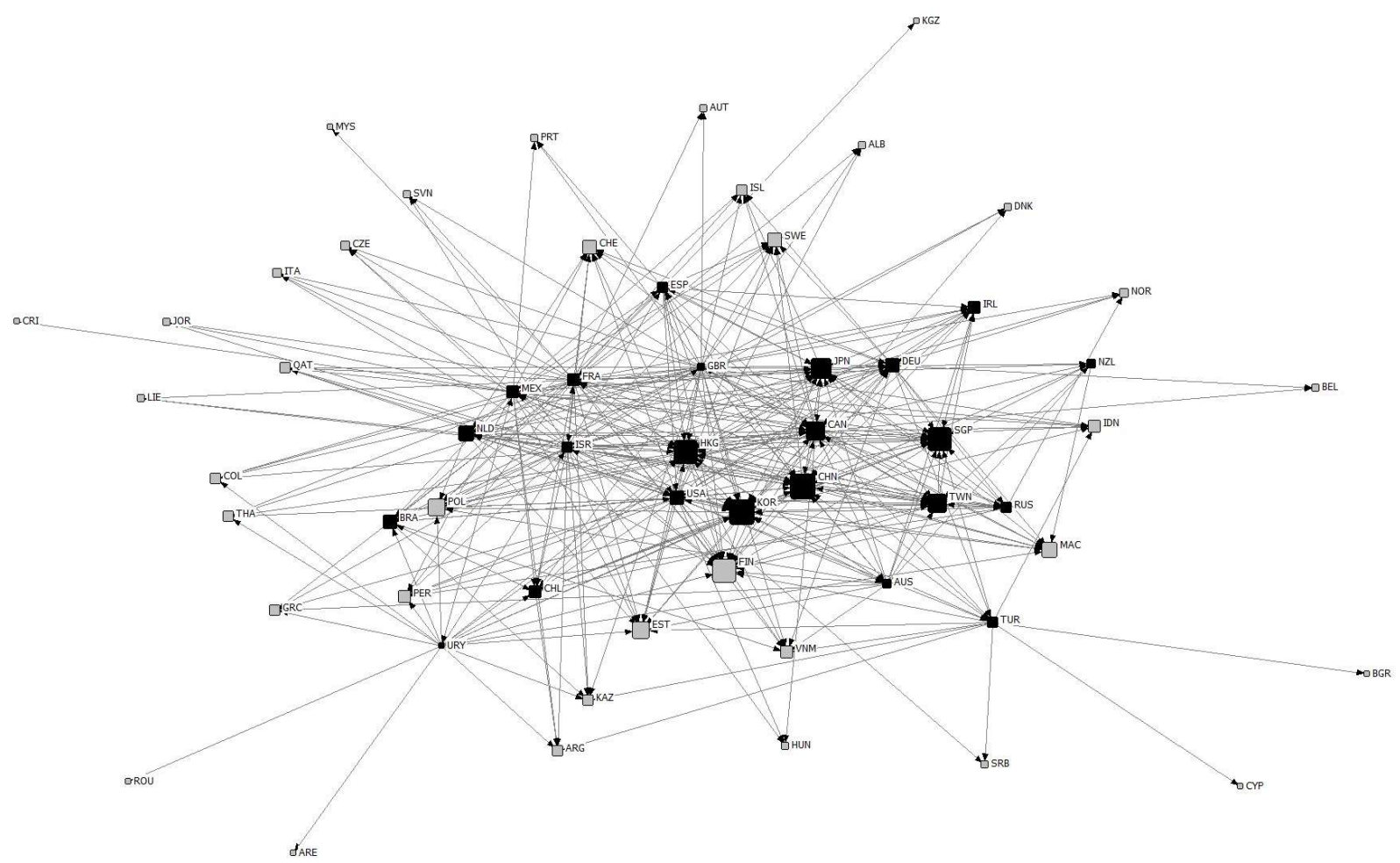

Note: The map is comprised of countries (represented in squares) and ties (represented in lines) between countries that referenced each other. The direction of the arrow in the end of the line indicates the direction of the relation (source $>$ reference). Countries in our sample $(n=23)$ are marked in black, whereas other countries mentioned in newspapers are marked in grey. The size of each node/country reflects the number of countries that referenced that country. 